\title{
PEMODELAN MOBILE GIS SEJARAH HIDUP NABI MUHAMMAD SAW BERBASIS ANDROID
}

\author{
${ }^{1)}$ Luluk Elvitaria, ${ }^{2)}$ Liza Trisnawati \\ 1)2)Teknik Inforamtika, Teknik, Universitas Abdurrab \\ Jl. Riau Ujung, Pekanbaru, 28282 \\ E-Mail :luluk@univrab.ac.id,liza.trisnawati@univrab.ac.id
}

\begin{abstract}
ABSTRAK
Untuk mengambil suri teladan dari kehidupan nabi Muhammad SAW maka penulis tertarik untuk membuat sebuah aplikasi SIG untuk membantu pencarian tempat -tempat bersejarah dari perjalanan hidup nabi Muhammad disertai dengan keteladan yang dapat diambil dari setiap kejadian ditempat beliau berada dengan mudah, cepat dan informatif. Tujuan dalam penelitian ini adalah bagaimana membuat SIG tentang informasi Sejarah Hidup Nabi Muhammad SAW menggunakan sistem operasi Android. Hasil yang didapat dalam penelitian ini bagaimana menyajikan SIG Sejarah Hidup Nabi Muhammad SAW dapat diakses melalui mobile phone.
\end{abstract}

Kata Kunci: Android, SIG, sejarah Muhammad SAW

\section{ABSTRACT}

To take an example from the life of the prophet Muhammad SAW, the author is interested in creating a GIS application to help search historic places from the life journey of the Prophet Muhammad accompanied by the example that can be taken from any event where he is easily, quickly and informally. The purpose of this research is how to make GIS about information on the Life History of the Prophet Muhammad using the Android operating system. The results obtained in this study are how to present the GIS of the Life History of the Prophet Muhammad can be accessed through a mobile phone.

Keywords: Android, GIS, history of Muhammad SAW

\section{PENDAHULUAN}

Perkembangan ilmu pengetahuan dan teknologi yang sangat pesat, membuat masyarakat membutuhkan informasi yang bersifat cepat, akurat, dan mudah didapat. Dengan berkembangnya teknologi seperti smartphone Android membuat masyarakat memerlukan aplikasi yang dapat dibawa kemana-mana atau berbasis mobile. Smartphone dapat difungsikan sebagai mobile computer karena adanya dukungan processor yang semakin canggih dan kapasitas memori yang semakin besar. Keunggulan lainnya adalah adanya perangkat GPS (Global Position System) sehingga smartphone dapat dijadikan alat navigasi atau pemandu jalan bagi pemiliknya.

Sistem Informasi Geografis (SIG) juga dapat digunakan sebagai alat bantu utama yang interaktif, menarik, dan menantang di dalam usaha-usaha untuk meningkatkan pemahaman, pengertian, pembelajaran mengenai konsep lokasi, ruang (spasial), kependudukan dan unsur-unsur geografis yang terdapat di permukaan bumi

berikut data atribut terkait yang menyertainya.

Sejarah hidup Nabi Muhammad SAW merupakan teladan aplikatif dan ajaran islam yang bisa dijadikan rujukan bagi umat Isalm di sepanjang zaman dalam menghadapi berbagai persoalan kehidupan yang dihadapi manusia. Pada diri nabi Muhammad SAW terdapat keteladaan dalam berbagai aspek kehidupan, seperti ibadah, peranan sebagai kepala rumah tangga, peranan sebagai kepala negara, kesabaran menghadapi musibah, ketegarannya di atas kebenaran, ketenangannya mengahadapi goncangan dunia. Nabi Muhammad SAW senantiasa menjadi sumber seluruh sejarah kemanusiaan, dan duniapun menjadikan beliau sebagai acuan sistem pemikiran yang 
benar.

Untuk mengambil suri teladan dari kehidupan nabi Muhammad SAW maka penulis tertarik untuk membuat sebuah aplikasi SIG untuk membantu pencarian tempat -tempat bersejarah dari perjalanan hidup nabi Muhammad disertai dengan keteladan yang dapat diambil dari setiap kejadian ditempat beliau berada dengan mudah, cepat dan informatif.

\section{Sistem Informasi Geografis}

Geografi pada umumnya adalah ilmu yang mempelajari tentang lokasi serta persamaan dan perbedaan variasi keruangan atas fenomena fisik dan manusia diatas permukaan bumi. Geografi lebih dari sekedar kartografi (studi tentang peta). Geografi tidak hanya menjawab apa dan dimana yang ada diatas muka bumi, tetapi juga diartikan dengan lokasi pada ruang (Denny. C, 2004).

$$
\text { Sistem Informasi Geografis }
$$

Geographic Information System (GIS) adalah sistem informasi khusus yang mengelola data yang memiliki informasi spasial untuk membangun, menyimpan, mengelola dan menampilkan informasi berefrensi geografis (Gistut, 1994 dalam Prahasta, 2009:85).

Sistem Informasi Georafis merupakan suatu sistem informasi yang berbasis komputer, dirancang untuk bekerja dengan menggunakan data yang memiliki informasi spasial (bereferensi keruangan). Sistem ini mengcapture, mengecek, mengintegrasikan, memanipulasi, menganalisa, dan menampilkan data yang secara spasial mereferensikan kepada kondisi bumi.

Menurut Gistut (1994) dalam Prahasta (2009:85), SIG adalah sistem yang dapat mendukung pengambilan keputusan spasial dan mampu mengintegrasikan deskripsi-deskripsi lokasi dengan karakteristik-karakteristik fenomena yang ditemukan di lokasi tersebut.
Prahasta (2009:85), mendefinisikan SIG adalah sistem berbasis komputer yang digunakan untuk memasukan, menyimpan, mengelola, menganalisis dan mengaktifkan kembali data yang mempunyai referensi keruangan untuk berbagai tujuan yang berkaitan dengan pemetaan dan perencanaan. Dari defenisi-definisi tersebut diatas dapat diambil kesimpulan bahwa SIG terdiri atas beberapa subsistem, yaitu data input, data output, data management, data manipulasi dan analisis (Prahasta, 2009:85).

SIG adalah sistem komputer yang digunakan untuk mengumpulkan, memeriksa, mengintegrasikan, dan menganalisa informasiinformasi yang berhubungan dengan permukaan bumi (Prahasta, 2009:62). Sedangkan menurut ESRI definisi SIG adalah kumpulan yang terorganisir dari perangkat keras komputer, perangkat lunak, data geografi dan personil yang didesain untuk memperoleh, menyimpan, memperbaiki, memanipulasi, menganalisis, dan menampilkan semua bentuk informasi yang bereferensi geografi (Prahasta, 2009:62).

Menurut Purwadhi (1994) dalam (Prahasta, 2009:85), SIG merupakan suatu sistem yang mengorganisir perangkat keras (hardware), perangkat lunak (software), dan data, serta dapat mendaya-gunakan sistem penyimpanan, pengolahan, maupun analisis data secara simultan, sehingga dapat diperoleh informasi yang berkaitan dengan aspek keruangan.

\section{Sub SIG}

(SIG) menyediakan empat perangkat kemampuan untuk menangani data tereferensi secara geografi, yakni :
Menurut Burrough (1986) dalam 


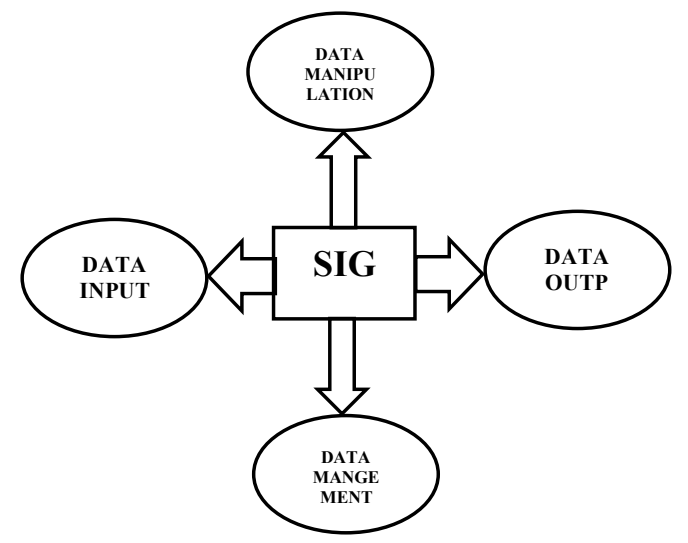

Gambar 1. Sub-Sistem GIS

\section{Komponen-komponen SIG}

Menurut Matzachri (2015) SIG merupakan sistem kompleks yang biasanya terintegrasi dengan lingkungan sistem-sistem komputer yang lain ditingkat fungsional dan jaringan. Sistem SIG terdiri dari beberapa komponen berikut :

\section{a. Perangkat keras}

SIG tersedia untuk berbagai platform perangkat keras mulai dari PC, workstation, hingga multi user host yang dapat digunakan oleh banyak orang dalam jaringan computer yang luas, berkemampuan tinggi, memiliki media penyimpanan (harddisk) yang besar, kapasitas memory (RAM) yang besar. SIG tidak terikat ketat terhadap karakteristik fisik perangkat keras ini, sehingga keterbatasan memori pada PC (misalnya) bisa diatasi.

\section{b. Perangkat lunak}

Sistem perangkat lunak yang tersusun secara modular dimana basis data sebagai kunci utamanya. Setiap sub-sistem diatas diimplementasikan dengan menggunakan perangkat lunak yang terdiri dari beberapa modul (bisa mencapai ratusan modul program yang dapat dieksekusi sendiri).

\section{c. Data dan Informasi Geografis}

SIG dapat mengumpulkan dan menyimpan data dan informasi yang diperlukan baik secara langsung maupun tidak langsung. Dengan cara mengimportnya dari perangkat lunak lain, maupun langsung dengan cara mendigitasi data spasialnya dari peta dan memasukkan data atributnya.

Sarana terpenting dalam SIG adalah basis data yang terpadu. Tanpa pengguna data secara bersama atau yang dikenal dengan istilah berbagai data (data Sharing), maka penyajian hasil analisis yang optimal tidak akan terjamin. Pengguna peta dasar yang sama (mempunyai georefensi sama) akan menjadikan data spasial dan informasi dapat disimpan dalam analisis pemecahan dan pengambilan keputusan.

\section{d. Manajemen}

Suatu proyek SIG akan berhasil jika di-manajemenkan dengan baik dan dikerjakan oleh orang-orang yang memiliki keahlian yang tepat pada semua tingkatan. Dalam hal ini mengorganisasikan data spasial maupun atribut dalam format yang sama, sehingga mudah digunakan dalam analisis pemecahan dan pengambilan keputusan.

\section{Sejarah Hidup Nabi Muhammad SAW}

Nabi Muhammad SAW adalah anak Abdullah bin Abdul Mutalib. Ibunya bernama Aminah binti Wahab. Kedua orangtuanya berasal dari suku Quraisy yang terpandang dan mulia. Nabi Muhammad SAW lahir pada hari Senin, 12 Rabi'ul Awal tahun Gajah (atau, 20 April 571 Masehi). Dinamakan tahun Gajah, karena ketika beliau lahir, kota Makkah diserbu oleh Raja Brahah dan tentaranya dari negeri Habasyah dengan mengunggag gajah. Mereka hendak menghancurkan Ka'bah karena iri hati terhadapnya. Tetapi Allah melindungi bangunan suci itu dan seluruh penduduk Mekkah, dengan menjatuhkan batu-batu Sijjil 
(dari neraka) yang amat panas kepada tentara itu. Maka binasalah mereka semua.

Ketika Nabi Muhhamad SAW masih dalam kandungan Ibunya, Abdullah ayahnya pergi ke negri Syam (Siria) untuk berdagang. Tetapi sepulang dari sana, ketika sampai di kota Madinah, ia menderia sakit dan wafat pada usia 18 tahun. Abdullah dimakamkan di Kota Madinah. Maka Nabi Muhammad SAW dilahirkan ke dunia dalam keadaan yatim, ditengah-tengah masyarakat jahilliyah penyembah berhala, penindas kaum lemah, perampas hak orang dan bahkan membunuh kaum wanita.

Nabi Muhammad SAW adalah manusia dan sekaligus merupakan suatu gerak dalam kemajuan manusia. Diantara mu'jizatnya adalah sejarahnya penuh dengan hal-hal yang tidak terdapat dalam sejarah manusiamanusia lainnya.Seluruh keadaannya telah diformat secara ilahiah, seolah-olah merupakan sifat-sifat yang yang telah dibentuk oleh Allah lalu digantungkan pada sejarah untuk nilai-nilai kehidupan, seperti halnya matahari yang digantungkan di langit untuk sumber kehidupan (Mubarakfury, 1998).

Sejarah Hidup Rasulullah meliputi :

1. Kelahiran dan Empat Puluh Tahun sebelum Nubuwah

2. Dibawah naungan Nubuwah dan Risalah

3. Perintah Dakwah

4. Pembaoikotan Umum

5. Akhir Utusan Quraisy kepada Abu Thalib

6. Tahun Duka Cita

7. Menawarkan islam kepada Kabilahkabilah dan Pribadi

8. Isra' dan mi'raj

9. Bai'at Aqabah Pertama

10. Bai'at Aqabah Kedua

11. Di "Parlemen Quraisy" Darun Nudwah
12. Kehidupan di Madinah

13. Perjanjian dengan Yahudi

14. Perjuangan berdarah

15. Perang Badr Kubra

16. BerbagaiOperasi Militeer antara Badr dan Uhud

17. Perang Uhud

18. Ekspansi antara Uhud dan Ahzab

\section{Google Maps API}

Google Maps merupakan layanan aplikasi peta online yang disediakan oleh Google secara gratis. Layanan peta Google Maps secara resmi dapat diakses melalui situs http://maps.Google.com.

Google Maps mempunyai banyak fasilitas yang dapat di pergunakan misalnya pencarian lokasi dengan memasukkan kata kunci, kata kunci yang dimaksud seperti nama tempat, kota atau jalan, fasilitas lainnya yaitu perhitungan rute perjalanan dari satu tempat, ke tempat lain Google Maps. (https://developers.google.com/maps. 2015)

\section{Android}

Menurut Yosep M (2014) Android adalah kumpulan perangkat lunak yang ditujukan bagi perangkat bergerak mencakup sistem operasi, middleware, dan aplikasi kunci. Android Standart Development Kid (SDK) menyediakan perlengkapan dan ApplicationProgramming Interface (API) yang diperlukan untuk mengembangkan aplikasi pada platform android menggunakan bahasa pemrograman Java. Android dikembangkan oleh Google bersama Open Handset Allience (OHA) yaitu aliansi perangkat selular terbuka yang terdiri dari 47 perusahaan Hardware,Software dan perusahaan telekomunikasi ditujukan untuk mengembangkan standar terbuka bagi perangkat selular.

Android adalah sebuah operating system yang dikhususkan untuk perangkat mobile 
(bukan PC). Basis dari Android adalah open source yang dikenal dengan nama Linux. Sebelumnya Android Inc. berdiri secara independen yang didirikan pada tahun 2003 oleh Andy Rubin, Rich Miner, Chris White, dan Nicks Sears. Android Inc. bermarkas di Palo Alto, California. Perusahaan berusaha untuk mengembangkan sebuah operating system mobile yang lebih canggih dari operating system mobile kala itu. Kemudian pada Agustus 2005 Google mengajukan penawaran untuk mengakuisisi perusahaan tersebut. (Pelabiran, M, 2015).

\section{METODE}

\section{Kerangka Kerja Penelitian}

Untuk mempermudah dalam pengerjaan penelitian ini, maka penulis membuatkan kerangka kerja penelitian seperti pada gambar 3.1 berikut ini.

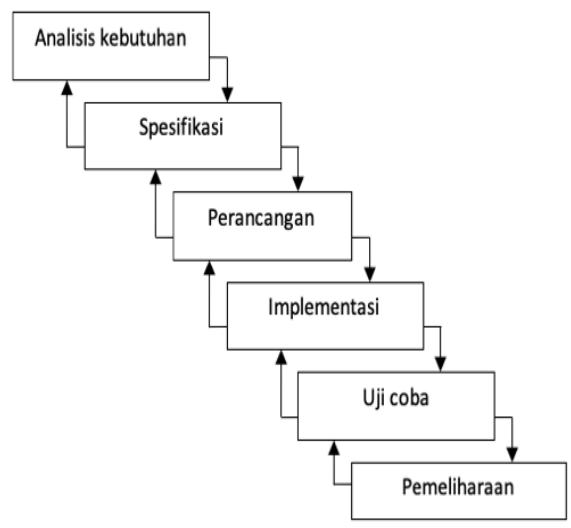

Gambar 2. Kerangka Kerja Penelitian

Gambar 2 merupakan kerangka kerja yang digunakan dalam langkah langkah penelitian. Metode penelitian yang digunakan pada penelitian ini adalah metode historis, dimana metode historis bertujuan merekonstruksi masa lalu secara sistematis dan objektif dengan mengumpulkan, menilai, memverifikasi, dan menyintesiskan bukti untuk menetapkan fakta dan mencapai kongklusi yang dapat dipertahankan.

\section{Analisis Masalah}

Tahap identifikasi masalah merupakan tahap awal pada suatu penelitian tahap ini dilakukan dengan melihat latar belakang dari penelitian, kemudian melihat batasan masalah dan selanjutnya melakukan perancangan sistem informasi geografis.

\section{Spesifikasi data}

Pengumpulan data merupakan langkah kedua dalam melakukan penelitian. Data dikumpulkan dari berbagai sumber yang ada. Pengumpulan data pada penelitian ini dilakukan dengan 3 metode yaitu metode wawancara, studi pustaka (literature), dan laboratorium (laboratory research).

\section{Wawancara}

Metode yang paling banyak digunakan yang melibatkan pembicaraan dengan informasi secara langsung dalam suatu wawancara. Wawancara ialah proses komunikasi atau interaksi untuk mengumpulkan informasi dengan cara tanya jawab antara peneliti dengan informan atau subjek penelitian. Wawancara yang dilakukan penulis pada penelitian ini adalah, melakukan wawancara tentang Sejarah Hidup Nabi Muhammad SAW pada Ulama-ulama pakar Sirah Nabawiyah. Dengan mengumpulkan data lewat informasi yang diberikan informasi kepada penulis, maka penulis akan mengumpulkan data hasil wawancara, kemudian merancang sistem informasi geografis tersebut.

\section{Penelitian kepustakaan (library research)}

Melakukan Penelitian di perpustakaan dengan cara mencari buku dan mempelajari literatur yang ada hubungannya dengan masalah yang diteliti. Hal ini sangat berguna untuk pedoman dan referensi bagi penulis. 


\section{Perancangan sistem}

Tahap penulisan proses data, aliran proses dan hubungan antar data yang paling optimal dan memenuhi kebutuhan pihak yang sesuai dengan hasil analisa kebutuhan.

\section{Perancangan Proses}

Rancangan proses menggunakan

Diagram Alir Data (DAD) pada sistem informasi geografis parawisata di Kota Pekanbaru.

\section{PPerancangan Flowchart}

Bagan alir program (flowchart) adalah suatu bagan yang menggambarkan arus logika dari data yang akan diproses dalam suatu program dari awal sampai akhir.

\section{Perancangan Basis Data}

Desain data adalah aktifitas penting yang dilakukan dalam rekayasa perangkat lunak. Pengaruh struktur program dan kompleksitas prosedural menyebabkan perancangan data berpengaruh penting terhadap kualitas perangkat lunak.

\section{Rancangan}

\section{Diagram (ERD)}

Entity-Relationship

ERD merupakan kumpulan konseptual untuk menggambarkan data, hubungan data, semantik (makna) dan batasannya. ERD disajikan dalam bentuk diagram hubungan entitas yang terdiri dari entitas, atribut, garis penghubung dan relasi.

\section{Relasi Antar Tabel}

Pemodelan data dalam merancang suatu database adalah dengan menggunakan model relasi antar tabel. Relasi antar tabel terdiri dari komponen-komponen: tabel, field, hubungan atau relasi dan jenis hubungan atau relasi.

\section{Perancangan Tabel}

Desain basisdata Rancan bangun sistem informasi Sejarah Hidup Nabi Muhammad SAW.

\section{Perancangan Antar Muka}

Rancangan antarmuka ini terbagi dalam 2 kelompok yaitu rancangan antar muka untuk user dan rancangan antar muka untuk admin.

\section{Implementasi dan Pengujian Sistem}

Pada tahap ini penulis mengimplementasikan sistem berdasarkan rancangan yang telah dibuat sebelumnya sesuai dengan kebutuhan pihak terkait. Dan tahap pengujian terhadap sistem yang telah dibuat sekaligus mengevaluasi kekurangan serta kelebihan sistem tersebut.

\section{Pemeliharaan}

Tahap ini dilakukan guna mengevaluasi sistem yang telah dibuat guna memperoleh hasil yang optimal, dan perawatan terhadap sistem bertujuan agar sistem yang sudah terpasang dapat berjalan semakin efektif dan efisien, perawatan sistem baru harus dilakukan secara berturut turut dan terencana. Apabila program terdapat error, maka akan diadakan perbaikan pada program dengan cara memperbaiki dan menghilangkan eror yang terjadi sampai program dapat digunakan dengan baik dan sempurna.

\section{Alat dan Bahan Penelitian}

Spesifikasi hardware pada Laptop/ PC yang digunakan dalam penelitian ini yaitu:

Personal Computer (PC) atau Laptop

Personal komputer atau laptop yang digunakan untuk perancangan perangkat lunak dan merupakan sebagai alat testing untuk sistem informasi geografis wilayah rawan banjir di Kota Pekanbaru, dengan spesifikasi sebagai berikut :

\begin{tabular}{ll} 
a. & Merk Perangkat : Personal \\
& Computer (PC) atau Laptop \\
b. & Prosessor : Dual CPU @2430M \\
& CPU \# 240 Ghz \\
c. & Memori 4 GB \\
\hline 9 & Penulis Pertama : Luluk Elvitaria
\end{tabular}




\section{d. DirectX Version : DirectX 11}

e. VGA : Intel (R) G41 Expres Chipset

f. Type System : 32-bit Operating System.

Software-software yang digunakan dalam pembuatan program sistem informasi geografis ini antara lain :

1. Bahasa pemrograman : Java

2. MySQL untuk membuat Basis data (database)

3. Web Browser Mozilla Firefox 15.0.1, Chrome.

4. Microsoft Visio 2007 untuk membuat Rancangan Program

\section{HASIL}

\section{Use Case}

Pada tahap pembuatan use case, dilakukan dengan melakukan analisis kebutuhan, yaitu apa saja yang dibutuhkan oleh pengguna aplikasi dalam menjalankan aplikasi nantinya, adapun tahap awal yang dilakukan adalah membuat usecase :

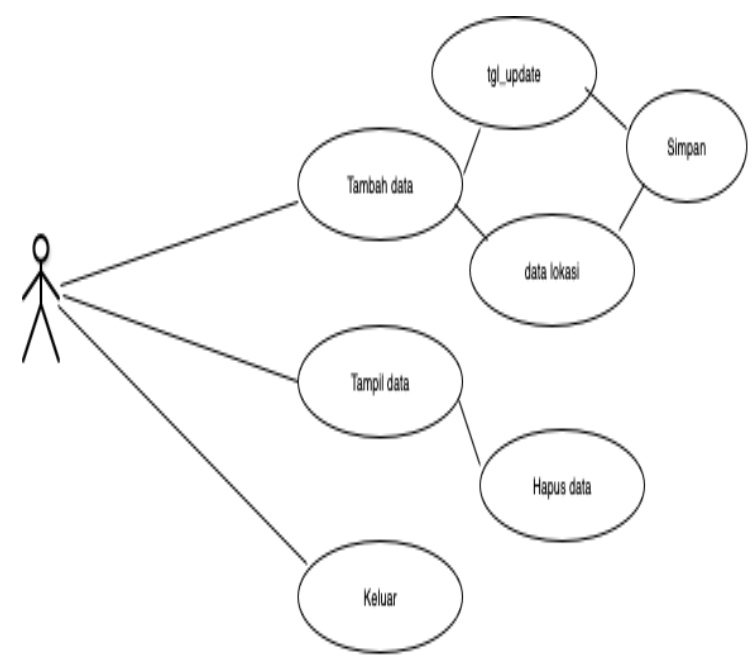

gambar 4.1 diatas merupakan aktifitas yang akan dilakukan oleh user, aktifitas yang dapat dilakukan adalah, tambah data lokasi, data sejarah dan data-data yang berkaitan dengan kebutuhan aplikasi.

\section{Pemodelan}

Pemodelan yang pertama dilakukan dalam aplikasi ini adalah membuat model layout untuk login user/admin, dalam pemodelna untuk layout login ini digabungkan untuk hak akses user dan hak akses super admin yang mana aktifitas keduanya dibedakan setelah melakukan proses login. Untuk gambar layout login dapat dilihat pada gambar 4 .

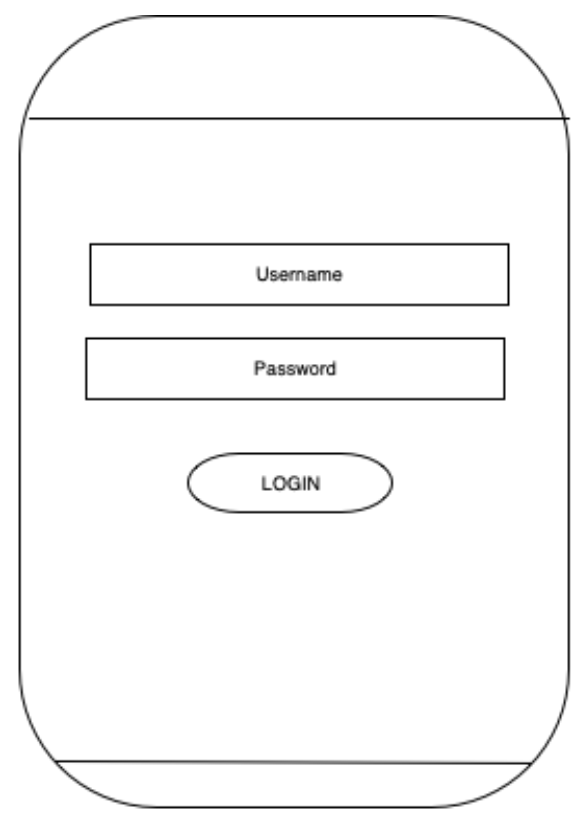

Gambar 4. Login user dan admin

Untuk selanjutnya akan dibuat rancangan interface untuk menambah data lokasi dengan memasukkan data tanggal input, data koordinat dan nama lokasi, seoerti gambar 5 dibawah ini.

Gambar 3. Use case menu utama

Dalam proses yang dilakukan pada 


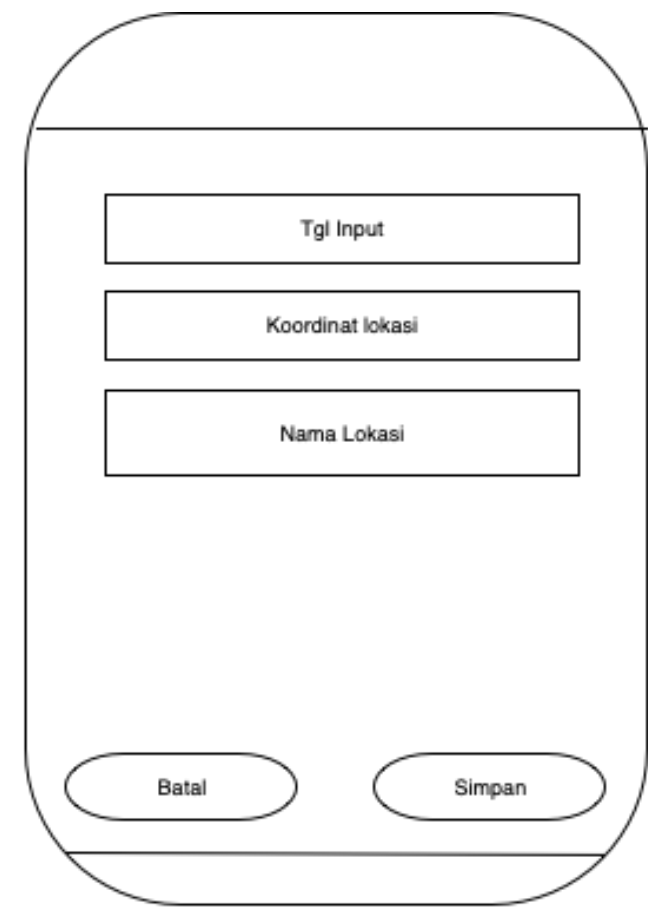

Gambar 5. interface tambah data lokasi

Untuk interface tambah data sejarah, dilakukan dengan beberapa tahap, yaitu input tanggal tambah data, input judul sejarah dan kemudian data sejarah yang akan di tampilkan pada interface pengguna/user, input data sejarah seperti gambar 6 .

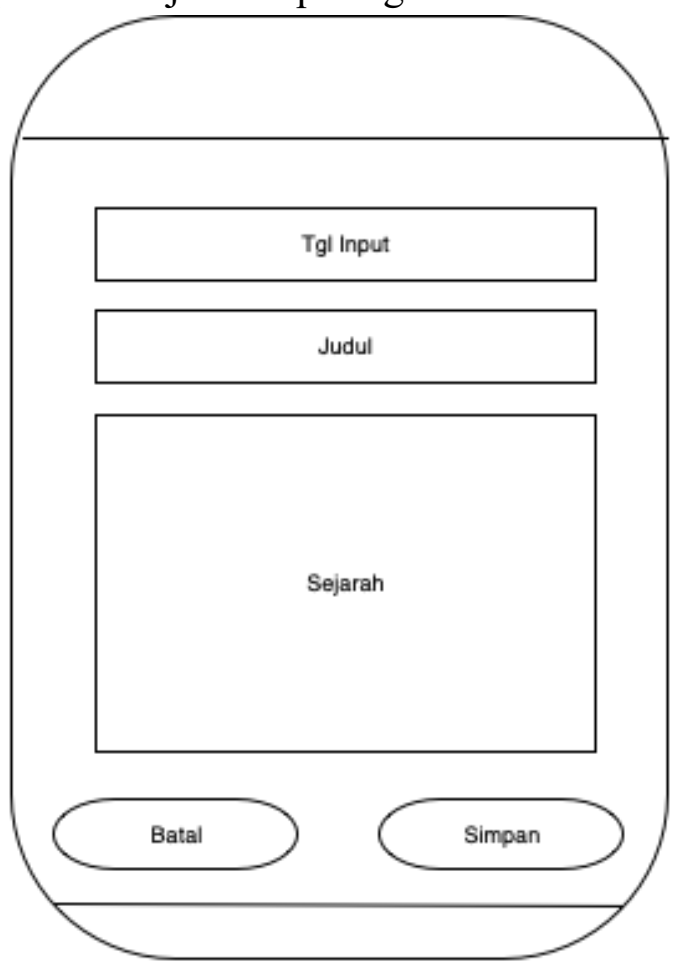

Gambar 6. pengguna/user
Untuk perancangan model interface yang akan digunakan oleh user yaitu, user/pengguna dapat menggunakan apolikasi ini dengan cara mencari lokasi yang tempat sejarah tersebut berada, tahap pencarian di berika dua fasilitas, pengguna dapat mencari lokasi dengan cara input titik koordinat atau dengan cara melihat langsung peta yang sudah ada pada interface, untuk lebih jelasnya dapat dilihat pada gambar 7 .

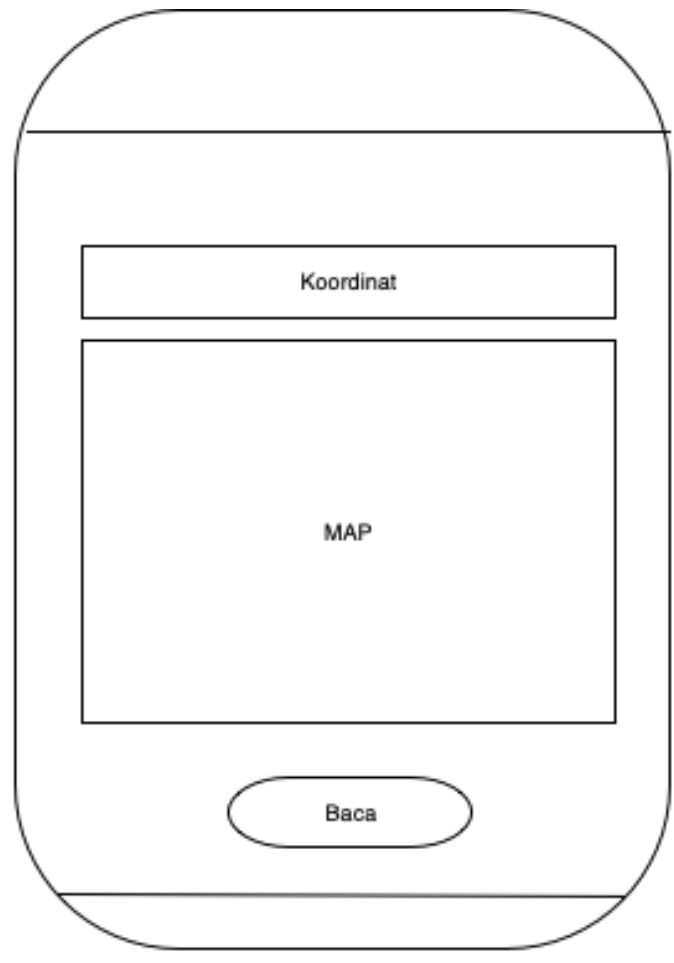

Gambar 7. Proses pencarian lokasi

Setelah lokasi didapatkan dan dipilih, maka akan tampil layout yang berisi list atau daftar judul sejarah yang dapat di baca pada lokasi yang sudah dipilih sebelumnya, gambar 8 . 


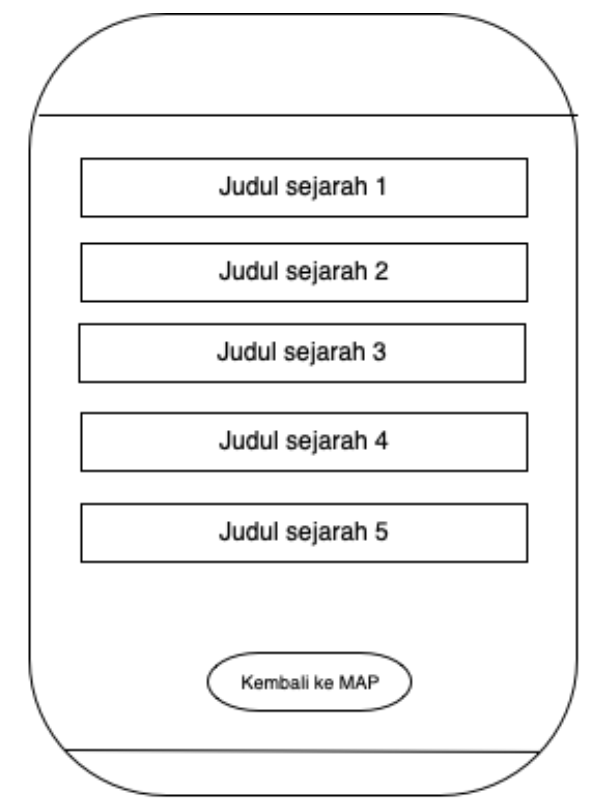

Gambar 8. tampilan daftar judul berdasarkan lokasi yang dipilih

Selanjutnya pada interface setelah salah satu judul di piluh makan akan menampilkan layout seoerti gambar 9 dibawah ini.

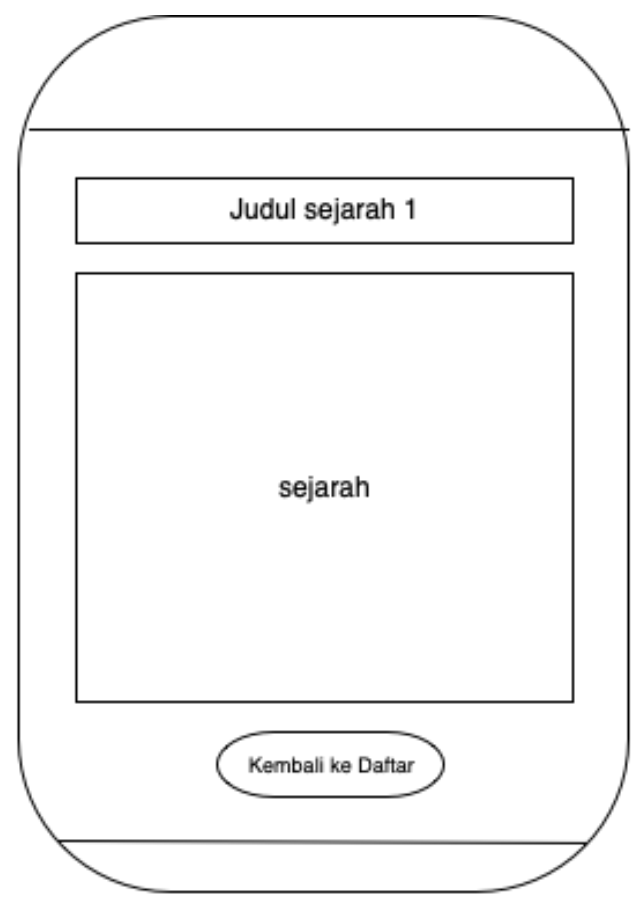

Gambar 9. interface untuk membaca sejarah berdasarkan judul yang dipilih

\section{KESIMPULAN}

Dari pemodelan yang telah dibuat, maka didapatlah sebuah kesimpulan, bahwa dalam membuat sebuah pemodelan maka yang harus dilakukan terlebih dahulu adalah anaislisis kebutuhan aplikasi yang akan di modelkan, dalam pembuatan pemodelan diperlukan langkah-langkah yang teratur dan terstruktur guna menghasilkan model yang di inginkan untuk dapat dilanjutkan pada tahap pembuatan aplikasi

\section{DAFTAR PUSTAKA}

[1]. Devi farela. (2014). celebrty endorser, daya tarik iklan, brand awreness dan brand attitude. Jurnal Manajemen Dan Bisnis, 11(1).

[2]. Gozali, I. (2011). Aplikasi Analisis Multivariat dengan Program. Semarang: Universitas Diponegoro.

[3]. Hermawan, H. (2017). Pengaruh Daya Tarik Wisata, Keselamatan, Dan Sarana Wisata Terhadap Kepuasan Serta Dampaknya Terhadap Loyalitas Wisatawan : Studi Community Based Tourism di Gunung Api Purba Nglanggeran. Jurnal Media Wisata, 15, 562-577.

[4].Iskandar. (2008). Metodologi Penelitian Pendidikan dan Sosial (kuantitatif dan kualitatif). Jakarta: Gaung Persada Press.

[5].Kumala, A. E., Borman, R. I., \& Prasetyawan, P. (2018). Sistem Informasi Monitoring Perkembangan Sapi Di Lokasi Uji Performance ( Studi Kasus: Dinas Peternakan Dan Kesehatan Hewan Provinsi Lampung ). Jurnal TEKNOKOMPAK, 12(1), 59.

[6].Lita, R. P. (2010). Pengaruh Implementasi Bauran Pemasaran Jasa Terhadap Proses Keputusan Wisatawan Mengunjungi Objek Wisata Di Kota Padang. Jurusan Manajemen Fakultas Ekonomi 
Universitas Jambi, 2(2), 91-99.

[7]. Santoso, S. (2014). SPSS 22 from essential to expert skills. Jakar: Elex Media Komputindo.

[8].Suparyogo, I. (2001). Metode Penelitian Kuantitatif Kualitatif dan R\&D. Bandung: Alfabeta. Yogyakarta: Andi.

[9].Thohari, S. (2014). Pandangan Disabilitas dan Aksesibilitas Fasilitas Publik bagi Penyandang Disabilitas di Kota Malang. Journal of Disability Studies, 1(1), 27-37.

[10]. Wahyu, R., \& Nurmalina, R. (2006). Analisis Kepuasan Pengunjung Dan Pengembangan Fasilitas Wisata Agro (Studi Kasus di Kebun Wisata Pasirmukti, Bogor). Jurnal Agro Ekonomi, 24, 41-59.

[11]. Windiyani, T. (2012). Opini Instrumen Untuk Menjaring Data Interval . Nominal, Ordinal Dan Data Tentang Kondisi, Keadaan , Hal Tertentu Dan Data. Jurnal Pendidikan Dasar, 3(5), 203-207. 